\title{
Efektivitas Peraturan Sekolah Tentang Larangan Siswa Membawa Smartphone di SMA Negeri 7 Padang
}

\author{
Wiwin Andesta ${ }^{1}$, Reno Fernandes ${ }^{2}$ \\ 1,2Universitas Negeri Padang \\ Email: wiwinandesta97@gmail.com, renofernandes@ fis.unp.ac.id
}

\begin{abstract}
Abstrak
Revolusi industri 4.0 yang ditandai dengan pesatnya perkembangan teknologi, informasi dan komunikasi membawa perubahan sosial dalam masyarakat. Menyikapi hal itu institusi pendidikan mengambil langkah inovasi dengan melahirkan pendidikan abad 21. pendidikan abad 21 mengharuskan siswa menguasai 4c (communication, collaboration, critical thingking, dan creativity), pengetahuan dan kemampuan literasi digital, literasi informasi, literasi media, dan menguasai teknologi informasi dan komunikasi. Penciri dari pembelajaran abad 21 adalah pemanfaatan teknologi informasi dan komunikasi dalam pembelajaran. Salah satu pemanfaatan teknologi dalam pembelajaran yaitu dengan memanfaatkan smartphone sebagai media pembelajaran yang bisa memunculkan berbagai informasi yang dapat menyeimbangi tuntuntan pembelajaran abad21. Adapun tujuan dari penelitian ini adalah untuk melihat sejauh mana Efektivitas Peraturan Sekolah Terhadap Larangan Siswa Membawa Smartphone di SMA Negeri 7 Padang, apakah aturan tersebut sudah berjalan dengan semestinya ataupun sebaliknya. Untuk menganalisis permasalahan penelitian ini, penulis penggunakan teori difusi inovasi yang dikemukakan oleh Everett M. Rogers. Penelitian ini menggunakan metode penelitian kualitatif dengan tipe studi kasus, dengan teknik pemilihan informannya yaitu purposive sampling. Dalam pengumpulan data dilakukan dengan cara observasi, wawancara, dokementasi dengan penelitian ini, peneliti menggunakan teknik analisis data dari Miles dan Huberman. Adapun hasil dari penelitian ini menunjukkan bahwa peraturan tentang larangan siswa membawa smartphone di SMA Negeri 7 Padang belum sepenuhnya efektif diterapkan. Karena masih siswa masih banyak yang melanggar aturan tersebut.
\end{abstract}

Kata kunci: Aturan, Pembelajaran abad 21, Smartphone

\section{Abstract}

The industrial revolution 4.0 marked by the rapit development of technology, information and communication brought social change in society. In respons to this, educational institutions are taking steps to innovate by giving birth to $21^{\text {st }}$ century education. $21^{\text {st }}$ century education requires students to master 4c (communication, collaboration, critical thingking, and creative), knowledge and digital literacy skill, information literacy, media litercy, and mastering technology. The hallmark of $21^{\text {st }}$ century learning is the use of information and communication technology in learning. One of the uses of technology in learning is to use a smartphone as a learning medium that can bring up various information that can balance the demans of $21^{s t}$ century learning. The purpose of this study is to see the extent of the Effectiveness of School Regulations Against the Prohibition of Students Carrying Smartphones in SMA Negeri 7 Padang, whether the rules are running properly or vice versa. To analyze the problem of this research, the writer uses social exchange theory proposed by George Casper Homans. This study uses qualitative research methods with the type of case study, with the selection of informant technique that is purposive sampling. In collecting data done by observation, interviews, documentation with this study, researchers used data analysis techniques from Miles and Huberman. The results of this study indicate that regulations regarding the prohibition of students from carrying a smartphone in SMA Negeri 7 Padang have not been fully effective. Because there are still many students who violate these rules.

Keywords: Rules, $21^{\text {st }}$ century learning, Smartphones 


\section{Pendahuluan}

Sekarang Indonesia telah menduduki era revolusi industri 4.0, dimana pada era ini ditandai dengan peningkatan konektivitas, interaksi dan pengembangan sistem digital, kecerdasan artifisial dan virtual. Tuntutan di dunia industri usia kerja 4.0 hanya dapat dipenuhi jika lulusan menjadi sumber daya manusia yang ditempa dari proses pendidikan yang memenuhi standar pendidikan 4.0 berdasarkan cyber system (Surani, 2019). Cara untuk menyelesaikan masalah revolusi industri 4.0 adalah setiap anak muda terutama siswa menyadari bahwa mereka ingin memperoleh keterampilan untuk menciptakan tenaga kerja profesional sangat diperlukan keseimbangan dengan keberadaan teknologi sekarang (Rezasyah, Darmawan, \& Rifawan, 2018).

Pendidikan yang bisa menyeimbangkan Era Revolution 4.0 adalah pembelajaran di abad ke-21. Abad 21 ini dicirikan dengan abad globalisasi atau abad keterbukaan, yang berarti bahwa kehidupan manusia pada abad 21 ini telah merasakan perubahan mendasar yang beda dari tatanan kehidupan di abad sebelumnya. Pada abad ke 21 ini dikenal dengan pesatnya perkembangan teknologi dan informasi, dan pada abad 21 pendidikan merupakan hal yang sangat penting bagi siswa untuk memperoleh keterampilan dalam belajar dan inovasi, keterampilan dalam memanfaatkan teknologi informasi dan media, kemampuan bekerja, bertahan hidup, dan menggunakan kecakapan hidup (life skills) (Wijaya, Sudjimat, \& Nyoto, 2016). Abad 21 sangat membutuhkan pendidikan sebagai ajang mempersiapkan diri supaya siswa mampu menghadapi persaingan ekonomi global sehingga mereka dapat bersaing dengan dunia (Hidayah, Salimi, \& Susiani, 2017).

Pembelajaran abad ke 21 menuntut para guru untuk dapat secara efektif mengajar dan mengelola kegiatan kelas, serta bisa menciptakan kolerasi yang efesiensi bersama siswa dan masyarakat di sekolah mereka, mampu memakai teknologi dalam menunjang pembelajaran, dan mencerminkan pembelajaran secara berkelanjutan. Pengembangan profesionalisme guru tidak hanya mencakup pengetahuan tentang pendekatan pengajaran dan strategi pembelajaran, tetapi juga tentang semua pengetahuan dan keterampilan yang terkait dengan kebutuhan guru yang mendukung pelatihan, seperti pengetahuan teknologi, manajemen emosi, dan keterampilan komunikasi (Muhali, 2019). Sistem pelatihan berdasarkan pada teknologi informasi dan komunikasi, adalah proses pendidikan yang menggambarkan penggunaan kemajuan teknologi untuk meningkatkan kualitas dan efektivitas proses pendidikan, yang diharapkan menjadi daya tarik khusus bagi siswa pada akhirnya (Chaidar, 2014).

Generasi $\mathrm{Z}$ atau disebut juga digital natives merupakan generasi yang tumbuh di era digital. Genarisi digital natives semakin menempatkan kehidupan dengan memakai komputer, video game, pemutar musik digital, camcorder, handphone, dan bermacam unit games yang dibuat di era digital. Generasi digital natives didorong oleh lingkungan, oleh karena itu mereka melihat teknologi digital bagaikan komponen integral dari hidupnya dan tidak bisa lepas dari internet sehingga membuat internet tumbuh sangat cepat (Mardiana, n.d.). Identitas generasi digital natives jadi ketertarikan khusus dan memasukan karakter dalam diri mereka. Dikarenakan antara karakter dan kepribadian amat menentang pertumbuhan dan perkembangan siswa. Keduanya berkembang dalam aspek kognitif, afektif dan psikokotor (Rahmandani, Tinus, \& Ibrahim, 2018). 
Memandu pemungutan Indonesia, APJII mengambil jumlah pengguna internet di Indonesia. Dimana pengguna internet Indonesia meningkat 10,12\% pada tahun 2018 dari pada tahun lalu. Jumlah keseluruhan pemakai internet mencapai 171,17 juta pemakai dari jumlah penduduk 264,16 juta jiwa. Dari 171,17 juta pemakai internet 2018, yang masih berkontribusi terbesar dalam peningkatan jumlah pemakai internet tersebut adalah pulau Jawa. Yang mana 55\% pemakai internet berada di Pulau Jawa. Diikuti oleh Pulau Sumatera 21\%, SulawesiMaluku-Papua 10\%, Kalimantan 9\%, dan Bali-Nusa Tenggara 5\% (APJII, 2019). Berdasarkan data dari pemasar, Indonesia memiliki lebih dari 100 juta pengguna smartphone aktif pada 2018. Ini menempatkan Indonesia di tempat keempat di dunia sebagai negara dengan pengguna smartphone terbanyak. Orang yang memiliki ponsel cerdas akan menemukan informasi lebih rajin. Berdasarkan hasil survei, rata-rata pengguna smartphone menggunakan perangkat mereka sehari selama 2 jam. Semasa durasi ini, mereka memakai perangkat mereka setiap hari untuk internet ( 24 menit 49 detik), media sosial (17 menit 29 detik), musik (15 menit 38 detik) dan permainan (14 menit 26 detik) (Rahmadani, Tinus, \& Ibrahim, 2018). Aplikasi smartphone yang biasa digunakan oleh kaum muda sebagai fungsi komunikasi adalah jejaring sosial seperti Facebook, Twitter, Path, Instagram, Blackberry Messenger, Line, dll (Nasution, Neviyarni, \& Alizamar, 2017).

Generasi saat ini berbeda dari generasi sebelumnya. Karena generasi sebelumnya tidak diperbolehkan membawa alat komunikasi ke sekolah, aturan tersebut tidak dapat diterapkan pada generasi saat ini. Karena teknologi digital adalah bagian yang sangat penting dalam kehidupan mereka, mereka akan menahannya dengan menolak membawa perangkat komunikasi seperti smartphone ke sekolah.

Namun realitanya di SMA Negeri 7 Padang justru menerapkan aturan dimana siswasiswi dilarang membawa smartphone ke sekolah. Hal ini tentu bertentangan dengan karakteristik siswa generasi digital natives dan juga tuntutan pembelajaran abad 21. Adanya larangan membawa smartphone ke sekolah ini dilakukan karena sekolah memiliki beberapa alasan yaitu tindakan siswa-siswi di SMA Negeri 7 Padang ini yang menyalahgunakan smartphone untuk hal-hal yang negatif seperti: bermain games saat proses pembelajaran, adanya group WhatsApp (WA) yang anggotanya sendiri merupakan siswa/siswi SMA Negeri 7 Padang, yang mana dalam group tersebut mereka tidak membahas tentang tugas-tugas sekolah melainkan group tersebut dijadikan sebagai media yang berisikan konten video porno, dan juga siswa menggunakan smartphone sebagai ajang bullying antara senior dan junior yang saling sindir menyindir melalui status WhatsApp.

Masalah-masalah tersebut dapat mengganggu aktivitas selama pembelajaran berlangsung serta juga dapat merusak kepribadian siswa sehingga pihak sekolah menggambil kebijakan untuk tidak memperbolehkan siswa membawa smartphone kesekolah. Setiap kebijakan yang dibuat oleh pihak sekolah pasti sudah dipikirkan terlebih dahulu secara matang, sehingga pihak sekolah juga sudah mengetahui sebab dan akibat yang akan ditimbulkan dari sebuah kebijakan tersebut. Walapun demikian kebijakan yang dibuat oleh pihak sekolah tersebut tentu sangat merugikan bagi siswa yang mana dengan dilarangnya siswa untuk membawa smartphone ke sekolah, siswa akan terbatas dalam mencari sumber pembelajaran, sehingga siswa menjadi kurang kreatif, kritis, dan aktif dalam proses pembelajaran. Hal ini dapat berpengaruh terhadap prestasi peserta didik, sehingga proses pembelajaran tidak mencapai tujuan. Selain itu adanya aturan tersebut juga membuat potensi yang dimiliki siswa menjadi terbatas dalam melaksanakan pembelajaran yang sudah menggunakan teknologi digital yang sesuai dengan tuntutan abad 21. 
Adapun penelitian yang relevan dengan penelitian ini adalah penelitian dari Siti Munawaroh (2016) yang berjudul "Pengaruh Peraturan Pembatasan Penggunaan Handphone Terhadap Perilaku Individual Santri Pesantren Nurul Ummah Putri Kota Gede Yogyakarta" (Munawaroh, 2016). Penelitian relevan yang kedua dari Alex Lendro Juniarto, Adelina Hasyim, dan Zulyaden Abdulhay (2012) dengan judul "Pengaruh Tata Tertib Sekolah Untuk Tidak Membawa Handphone Berkamera Terhadap Kenyamanan Belajar Pada SMP Negeri 7 Kotabumi” (Juniarto, Hasyim, \& Abdulhay, 2012).

\section{Metode Penelitian}

Penelitian mengenai Efektivitas Peraturan Sekolah Tentang Larangan Siswa Membawa Smartpone Di SMA Negeri 7 Padang menggunakan penelitian kualitatif. Creswell mengatakan bahwa penelitian kualitatif merupakan sebuah proses penelitian ilmiah dalam memahami permasalahan manusia dalam lingkup sosial yang menerbitkan gambaran yang disiapkan secara keseluruhan, memberikan informasi yang kompleks dari narasumberi, serta dilakukan dalam setting yang alami tanpa adanya intrusi apa pun dari peneliti (Burgin, 2006). jenis penelitian ini adalah penelitian kualitatif dengan tipe studi kasus (case study) yaitu penelitian yang memberikan pusatkan perhatian pada kejadian sosial umum yang konkret dalam kehidupan masyarakat. Tujuan dari penelitian studi kasus ini adalah untuk memahami tentang suatu peristiwa secara mendalam.

Penentuan informan dalam tulisan ini dilakukan dengan teknik Purposive Sampling (sampel bertujuan). Teknik Purposive Sampling yaitu penetapan sampel berdasarkan penilaian tertentu. Berdasarkan teknik purposive sampling, penulis menentukan subjek dan lokasi penelitian bertujuan untuk mendalami atau menelateni persoalan pokok yang akan diteliti (Herdiansyah, 2014). Selain itu penulis juga melakukan teknik pengumpulan data dengan cara melakukan observasi, wawancara, dan dokumentasi. Teknik pengumpulan data adalah tindakan yang paling tetap dalam penelitian, adapun tujuan dari penelitian adalah untuk memperoleh data. Jika seorang penulis tidak tahu cara pengumpulan data, maka seorang penulis tidak akan memperoleh data yang sesuai standar yang telah ditentukan (Sugiyono, 2012). Agar data yang penulis peroleh dalam tulisan ini akurat, valid dan sah, maka dilakukan dengan teknik triangulasi data. Teknik analisis memakai teknik analisis data dari Miles dan Huberman dengan cara pengumpulkan data, reduksi data, penyajian data, dan penarik kesimpulan.

\section{Hasil dan Pembahasan}

Dalam latar belakang pembelajaran abad 21, menggunakan pembelajaran yang aktif, kritis, kolaborasi, kreatif, keterampilan berkomunikasi, dan mempertahankan keterampilan karakter, karena sebagai lembaga pendidikan siswa juga mempertahankan keterampilan teknik (Fernandes, 2019). Pembelajaran abad 21 menuntut siswa mampu menggunakan teknologi informasi sebagai sumber pembelajaran. Salah satunya dengan memanfaatkan smartphone sebagai media informasi untuk mencari berbagai sumber belajar. Smartphone merupakan alat komunikasi yang dapat digunakan diamanapun dan mempunyai fungsi serbaguna yang dapat memudahkan siswa untuk mencari informasi mengenai materi pelajaran atau informasi yang dibutuhkan pada saat proses belajar yang sesuai dengan tuntutan pembelajaran abad ke-21. Adapun manfaat Smartphone bagi pelajar adalah mempermudah anak dalam proses belajar seperti: browsing materi, mengunduh modul atau buku digital, anak juga bisa bimbel online 
melalui sebuah aplikasi, membantu anak dalam berkomunikasi, dan juga dapat memperluas hubungan sosialisasi anak. Namun smartphone juga memiliki dampak yang buruk bagi pelajar, yaitu dapat mempengaruhi sikap atau prilaku anak, menggagu konsentrasi anak saat belajar, lupa waktu, tumbuhnya sifat hedonisme pada anak, dan melemahkan otak anak karena mudahnya dalam mencari informasi sehingga anak malas untuk berfikir.

Seperti realita yang terjadi, banyak ditemukan siswa yang menyalahgunakan smartphone saat proses pembelajaran maupun diluar jam pembelajaran. Hal ini dapat mengganggu aktivitas selama pembelajaran berlangsung, serta juga dapat merusak kepribadian siswa sehingga pihak sekolah menggambil kebijakan untuk tidak memperbolehkan siswa membawa smartphone kesekolah. Salah satu sekolah yang menerapkan aturan tersebut adalah SMA Negeri 7 Padang.

Berdasarkan wawancara yang sudah dilakukan bersama pihak SMA Negeri 7 Padang mengenai aturan yang dikeluarkan oleh pihak sekolah bahwa kebijakan yang disudah sepakati oleh pihak sekolah, pihak komite, dan orang tua murid yang mengenai aturan larangan siswa membawa smartphone kesekolah belum efektif diterapkan di SMA Negeri 7 Padang. Karena aturan tersebut tidak sepenuhnya dipatuhi oleh peserta didik. Berdasarkan wawancara yang sudah peneliti lakukan dan juga pengamatan peneliti pada saat melakukan penelitian di SMA Negeri 7 Padang masih banyak ditemukan siswa-siswi yang memegang handphone, baik didalam kelas maupun di luar kelas.

Menurut peneliti ketegasan yang dilakukan oleh pihak sekolah terhadap aturan tersebut masih lemah, sehingga siswa-siswi tidak takut akan sanksi yang diberikan oleh pihak sekolah. Adapun alasan peneliti mengatakan tidak adanya ketegasan terhadap aturan tersebut adalah sebagai berikut:

\section{Razia}

Selama aturan diterapkan kurang lebih 6 bulan, pihak sekolah baru satu kali melakukan razia dan itupun dilakukan diawal penerapan aturan tersebut dan tidak pernah lagi melakukan razia sampai saat sekarang ini. Kalau razia dilakukan hanya sekali bagaimana siswa akan takut untuk membawa smartphone kesekolah. karena mereka merasa aman untuk membawanya dan tidak merasa takut akan dilakukan razia. Oleh karena itu siswa masih banyak membawa smartphone kesekolah.

\section{Pemberian Sanksi}

Bagi siswa yang melakukan pelanggar maka diberikan sanksi oleh pihak sekolah. Namun sanksi tersebut tidak membuat siswa atau siswi jerah. Karena sanksi yang diberikan kepada siswa-siswa yang ketahuan membawa smartphone kesekolah hanya ditahan satu minggu, dan bahkan ada diberikan hari itu langsung. Jika sanksi nya lebih tegas seperti smartphone ditahan selama satu semester atau selama berada di SMA tersebut maka anak akan jerah untuk membawanya kesekolah.

\section{Kurangnya ketegasan dari guru}

Waktu peneliti melakukan penelitian di SMA Negeri 7 Padang, peneliti banyak melihat siswa yang menggunakan smartphone mereka di depan gurunya. Tidak ada rasa takut sedikitpun yang dirasakan siswa saat menggunakan smartphone nya di depan guru mereka, dan tindakan guru hanya membiarkan saja siswa yang memainkan smartphone didepannya tanpa menegur atau mengambil smartphone tersebut. Jadi kalau tidak ada ketegasan dari pihak guru terhadap aturan tersebut, maka siswa dengan santainya akan melanggar dan tidak takut apabila mereka melanggar. 
Selain itu aturan tersebut tidak efektif karena siswa tidak tahan kalau berjam-jam tidak menggunakan smartphone, karena meraka terlalu sibuk dan terlena dengan dunia gadjet yang membuat mereka kecanduan dan tidak bisa terlepaskan. Selain itu smartphone merupakan alat yang memiliki banyak fungsi yang dapat memudahkan siswa dalam mencari sumber belajar, apapun yang mau mereka cari dengan menggunakan aplikasi google semuanya bisa terjawab tanpa perlu pikir panjang, sehingga siswa jadi ketergantungan dengan smartphone.

Setelah mendapatkan data diatas maka peneliti menganalisis efektivitas peraturan tentang larangan siswa membawa smartphone kesekolah memakai Teori Difusi Inovasi yang dikemukakan oleh Everett M. Rogers yang asumsinya adalah adanya sebuah proses untuk menebarkan sebuah ide terbaru dalam usaha untuk memperbaiki suatu masyarakat yang terjadi secara terus menerus dari satu tempat ke tempat yang lainnya, dari suatu jangka waktu ke jangka waktu berikutnya, dari suatu bidang tertentu ke bidang yang lainnya kepada sekelompok anggota dari sistem sosial.

Jadi asumsi dasar teori tersebut dapat dikaitkan bahwa inovasi yang dimaksud berupa kebijakan yang dikeluarkan oleh kepala SMA Negeri 7 Padang yang melarang siswanya untuk membawa smartphone kesekolah. Adapun tujuan dari kebijakan tersebut untuk mengatasi permasalahan-permasalahan yang terjadi yang ditimbulkan akibat dari kesalahan peserta didik dalam menggunakan smartphone yang dapat merusak moral. Namun inovasi yang dibuat oleh pihak sekolah tidak sepenuhnya diterima (adopsi) oleh peserta didik, masih banyak ditemukan peserta didik yang melanggar aturan tersebut. Karena menurut peserta didik aturan tersebut membuat mereka terbelenggu dan tidak bisa memanfaatkan kegunaan smartphone untuk memudahkan peserta didik dalam mengakses materi atau mencari sumber belajar.

Selain itu Siswa akan cendrung melanggar aturan dikarenakan pada masa lampau mereka diperbolehkan untuk membawa smartphone kesekolah, sehingga siswa cenderung untuk melakukan tindakan yang sama yaitu membawa smartphone ke sekolah karena sudah jadi kebiasaan bagi mereka untuk membawanya. Walaupun pihak sekolah telah melakukan berbagai caraa agar siswa menaati aturan tersebut, salah satunya dengan melakukan razia.

Namun razia yang dilakukan oleh pihak sekolah tidak akan membuat efek jerah bagi siswa-siswi yang masih membawa smartphone kesekolah. Karena hukuman yang mereka dapatkan sangat ringan dan mereka menganggap bahwa ganjaran yang diberikan merupakan hal yang biasa, sehingga tidak ada rasa bagi siswa takut untuk membawa smartphone kesekolah.

Rogers mengemukakan lima karakteristik inovasi meliputi:

\section{Keunggulan Relatif (relative advantage)}

SMA Negeri 7 Padang membuat suatu inovasi berupa aturan yang melarang siswa untuk tidak membawa smartphone ke sekolah. Aturan tersebut dibuat oleh pihak sekolah dengan tujuan mengatasi terjadinya permasalahan dilingkungan sekolah yang bisa merusak moral siswa. Selain itu dengan dilarangnya siswa membawa smartphone kesekolah, siswa bisa lebih fokus dalam proses pembelajaran.

\section{Kompatibilitas (compatibility)}

Menurut pihak sekolah dengan diadakan aturan tentang larangan siswa membawa smartphone kesekolah bisa membuat peserta didik lebih baik dari sebelumnya, yang mana pada saat siswa dibolehkan membawa smartphone kesekolah banyak terjadi permasalahan yang timbul dan dapat merusak moral peserta didik. Sehingga pihak sekolah membuat suatu kebijakan untuk mengatasi permasalahan yang terjadi. Akan tetapi kebijakan yang dibuat oleh 
pihak sekolah bertolak belakang dengan tuntutan pendidikan abad 21 dan generasi saat ini. Sehingga aturan tersebut sulit untuk dipatuhi oleh peserta didik.

\section{Kerumitan (complexity)}

Aturan yang dibuat oleh pihak sekolah sangat sulit dipatuhi oleh siswa, yang mana pada generasi saat ini yang disebut dengan generasi digital natives yang ketergantungan dengan smartphone. Dimana smartphone memiliki banyak fungsi yang membuat orang kecanduan sehinggah sulit dipisahkan dari diri individu. Selain itu aturan tersebut juga bertolak belakang dengan pembelajaran abad 21 yang menuntut siswa mampu memakai pembelajaran berbasis teknologi. Dengan diadakan aturan tersebut dapat menyulitkan siswa dalam mencari materi dan membuat siswa tidak kreatif dalam memanfaatkan teknologi.

\section{Kemampuan diuji cobakan (trialability)}

Sebelum pihak sekolah menerapkan aturan tersebut, pihak sekolah melakukan uji coba selama 3 bulan. Apakah aturan tersebut bisa diterapkan di SMA Negeri 7 Padang atau tidak. Setelah 3 bulan aturan tersebut masih diterapkan sampai saat sekarang ini. Pihak sekolah menganggap aturaan tersebut bisa diterapkan namun buktinya masih banyak peserta didik yang membawa smartphone kesekolah.

\section{Kemampuan diamati (observability)}

Setelah peneliti melakukan penelitian di SMA Negeri 7 Padang, masih banyak peneliti temukan siswa yang membawa smartphone kesekolah. Walaupun pihak sekolah sudah melakukan berbagai macam cara untuk siswa menaati aturan tersebut. Namun siswa tidak takut akan hukuman yang diberikan oleh pihak sekolah.

\section{Kesimpulan}

SMA Negeri 7 Padang merupakan salah satu sekolah yang melarang siswa-siswinya membawa smartphone kesekolah. Aturan ini diberlakukan pada bulan Oktober 2019, sebelumnya SMA Negeri 7 Padang membolehkan siswa-siswinya untuk membawa smartphone kesekolah. Namun dengan adanya beberapa permasalahan yang muncul akibat tindakan siswa/siswi di SMA Negeri 7 Padang ini yang menyalahgunakan smartphone untuk hal-hal yang negatif, maka pihak sekeloh membuat kebijakan untuk melarang siswa-siswi membawa smartphone kesekolah. Adapun upaya-upaya yang dilakukan pihak sekolah agar siswa-siswi mematuhi aturan tersebut dengan cara: melakukan razia mendadak agar siwa-siswi takut untuk membawa smartphone kesekolah.

Selain itu pihak sekolah juga memberikan hukuman bagi siswa-siswi yang masih kedapatan membawa smartphone kesekolah dengan syarat penangkapan pertama ditahan satu minggu, penangkapan kedua ditahan dua minggu, dan menangkapan ketiga ditahan satu bulan dan diberi surat pemanggilan orang tua. Hal tersebut diberlakukan agar siswa jerah untuk membawa smartphone kesekolah. Namun peraturan tersebut belum berjalan efektif, karena masih banyak siswa-siswi yang masih membawa smartphonenya kesekolah. Karena tidak ada ketegasan dari pihak sekolah terhadap aturan tersebut, sehingga siswa-siswi tidak takut akan sanksi yang sudah ditetapkan oleh pihak sekolah. 
Wiwin Andesta, Reno Fernandes Efektivitas Peraturan Sekolah Tentang Larangan Siswa Membawa Smartphone di SMA Negeri 7 Padang

\section{Daftar Pustaka}

APJII. (2019). Survei APJII yang Ditunggu-tunggu, Penetrasi Internet Indonesia 2018. Jakarta: APJII.

Burgin, B. (2006). Analisis Data Penelitian Kualitatif. Jakarta: Raja Grafindo Persada.

Chaidar, H. (2014). Pemanfaatan Teknologi Informasi dan Komunikasi dalam Pembelajaran di SMA Muhammadiyah Tarakan. Jurnal Kebijakan dan Pengembangan Pendidikan, 2(2), 184-192.

Fernandes, R. (2019). Relevansi Kurikulum 2013 dengan Kebutuhan Peserta Didik di Era Revolusi 4.0. Jurnal Socius: Journal of Sociology Research and Education, 6(2), 70-80. https://doi.org/https://doi.org/10.24036/scs.v6i2.157

Herdiansyah, H. (2014). Metodologi Penelitian Kualitatif untuk Ilmu-Ilmu Sosial. Jakarta: Salemba Humanika.

Hidayah, R., Salimi, M., \& Susiani, T. S. (2017). Critical Thinking Skill: Konsep dan Indikator Penilaian. Jurnal Taman Cendikia, 1(2), 127-133.

Juniarto, A. J., Hasyim, A., \& Abdulhay, Z. (2012). Pengaruh Tata Tertib Sekolah Untuk Tidak Membawa Handphone Berkamera Terhadap Kenyamanan Belajar Pada SMP Negeri 7 Kota Bumi. Jurnal Kultur Demokrasi, 1(2), 1-12

Mardiana, R. (2011). Potensi Digital Natives dalam Representasi Literasi Informasi Multimedia Berbasis Web di Perguruan Tinggi. Jurnal Pustakawan Indonesia, 11(1), 515.

Muhali, M. (2019). Pembelajaran Inovatif Abad Ke-21. Jurnal Penelitian dan Pengkajian Ilmu Pendidikan: E-Saintika, 3(2), 25-50.

Munawaroh, S. (2016). Pengaruh Peraturan Pembatasan Penggunaan Handphone Terhadap Perilaku Individual Santri Pesantren Nurul Ummah Putri Kotagede Yogyakarta. Prosiding. Universitas Negeri Yogyakarta.

Nasution, J. A., Neviyarni, S., \& Alizamar. (2017). Motif Siswa Memiliki Smartphone dan Penggunaannya. JPPI (Jurnal Penelitian Pendidikan Indonesia), 3(2), 15-29.

Rahmandani, F., Tinus, A., \& Ibrahim, M. M. (2018). Analisis Dampak Penggunaan Gadget (Smartphone) Terhadap Kepribadian dan Karakter (Kekar) Peserta Didik di SMA Negeri 9 Malang. Jurnal Civic Hukum, 3(1), 18-44. https://doi.org/10.22219/jch.v3i1.7726

Rezasyah, T., Darmawan, I., \& Rifawan, A. (2018). Kesiapan Siswa SMK dalam Revolusi Industri 4.0. (Studi pada SMK Global Mulia Cikarang). Kamawula : Jurnal Pengabdian Masyarakat, 1(2), 114-119.

Sugiyono, S. (2012). Metode Penelitian Kuantitatif, Kualitatif dan $R \&$ D. Bandung: Alfabeta

Surani, D. (2019). Studi Literatur: Peran Teknologi Pendidikan dalam Pendidikan 4.0. Prosiding Seminar Nasional Pendidikan. Universitas Sultan Ageng Tirtayasa

Wijaya, Y. E., Sudjimat, D. A., \& Nyoto, A. (2016). Transformasi Pendidikan Abad 21 sebagai Tuntutan Pengembangan Sumber Daya Manusia di Era Global. Prosiding Seminar Nasional Pendidikan Matematika. Universitas Kanjuruhan Malang. 